\title{
How Phosphorus Fertilization Alleviates the Effect of Salinity on Sugar Beet (Beta vulgaris L.) Productivity and Quality
}

\author{
Hamza Bouras ${ }^{1} \oplus$, Ahmed Bouaziz $^{1}$, Bassou Bouazzama $^{2}$, Abdelaziz Hirich $^{3, *}{ }^{\circledR}$ and Redouane Choukr-Allah ${ }^{1}$ \\ 1 Department of Crop Production, Protection and Biotechnology, Hassan II Institute of Agronomy and \\ Veterinary Medicine, Rabat 10101, Morocco; bourashamza07@gmail.com (H.B.); \\ hmadbouaziz@gmail.com (A.B.); redouane53@yahoo.fr (R.C.-A.) \\ 2 National Institute for Agricultural Research (INRA), Beni Mellal 23020, Morocco; \\ bassoubouazzama@gmail.com \\ 3 African Sustainable Agriculture Research Institute (ASARI), Mohammed VI Polytechnic University (UM6P), \\ Laayoune 70000, Morocco \\ * Correspondence: abdelaziz.hirich@um6p.ma; Tel.: +212-66-617-1546
}

\section{check for} updates

Citation: Bouras, H.; Bouaziz, A.; Bouazzama, B.; Hirich, A.;

Choukr-Allah, R. How Phosphorus Fertilization Alleviates the Effect of Salinity on Sugar Beet (Beta vulgaris L.) Productivity and Quality. Agronomy 2021, 11, 1491. https:// doi.org/10.3390/agronomy11081491

Academic Editors:

Manuel Nieves-Cordones and Francisco Rubio

Received: 22 June 2021

Accepted: 22 July 2021

Published: 27 July 2021

Publisher's Note: MDPI stays neutral with regard to jurisdictional claims in published maps and institutional affiliations.

Copyright: (c) 2021 by the authors. Licensee MDPI, Basel, Switzerland. This article is an open access article distributed under the terms and conditions of the Creative Commons Attribution (CC BY) license (https:// creativecommons.org/licenses/by/ $4.0 /)$.
Abstract: Salinity is a major problem affecting agriculture in many regions of the world, including Morocco. The best agronomic practices such as fertilization are used to cope with salinity stress and improve productivity under saline conditions. The objective of this study is to evaluate the interactive effect of phosphorus and salinity on sugar beet (Beta vulgaris L.) cv. "Sporta" productivity and quality. A field experiment was carried out, testing three levels of irrigation water salinity $(\mathrm{ECw}=0.7 ; 4$, 8 , and $\left.12 \mathrm{dS} \cdot \mathrm{m}^{-1}\right)$ and three levels of phosphorus $\left(100,120\right.$, and $140 \mathrm{~kg} \mathrm{P}_{2} \mathrm{O}_{5} \cdot \mathrm{ha}^{-1}$ ) organized in a split-plot design with three replicates. This research was conducted in the Tadla region (center of Morocco) during two seasons in 2019 and 2020. The obtained results show that irrigation water salinity had a negative effect on most growth and productivity parameters. For instance, sugar beet yield reduced by $21 \%$ and by $26 \%$ under saline irrigation, with an EC value equal to 4 and $8 \mathrm{dS} \cdot \mathrm{m}^{-1}$, respectively, compared to the control during the 2018-2019 season, and by $1 \%, 19 \%$, and $27 \%$ under saline irrigation, with an EC value equal to 4 and 8 and $12 \mathrm{dS} \cdot \mathrm{m}^{-1}$, respectively compared to the control $\left(0.7 \mathrm{dS} \cdot \mathrm{m}^{-1}\right)$ during the 2019-2020 season. Total sugar content was significantly increased by $5 \%$ and $7 \%$, respectively, under saline irrigation, with an EC value of 4 and $8 \mathrm{dS} \cdot \mathrm{m}^{-1}$, respectively, as compared with the control in the first growing season in 2018-2019. However, in the second growing season (2019-2020), only the highest level of saline water $\left(E C=12 \mathrm{dS} \cdot \mathrm{m}^{-1}\right)$ significantly increased in sugar content by $15 \%$ compared to the control. Regarding the $\mathrm{P}$ fertilization effect, it was found that a P rate of $120 \mathrm{~kg} \mathrm{P}_{2} \mathrm{O}_{5} \cdot \mathrm{ha}^{-1}$ was enough to improve the yield and sugar content of sugar beet under the tested salinity levels. Thus, $\mathrm{P}$ fertilization could be one of the best practices to enhance sugar beets' tolerance of salinity. To obtain a maximum root and sugar yield under saline water, it is recommended to apply a phosphorus dose of $120 \mathrm{~kg} \mathrm{P}_{2} \mathrm{O}_{5} \cdot$ ha $^{-1}$.

Keywords: stomatal conductance; yield; quality; root development; sugar content

\section{Introduction}

Salinity is a major problem that affects agricultural productivity by reducing the crop yield of a wide range of crop species in several regions of the world [1,2], and therefore, it affects agricultural production and income worldwide [3]. Salinization is continuously increasing in many parts of the world and has become a serious environmental problem facing the population, especially in arid regions. It has been estimated that more than half of agricultural lands could be salinized by the year 2050, mainly due to secondary salinization induced by human activity [4].

Estimates indicate that $50 \%$ of the irrigated land in some regions in North Africa has been affected by salinity [5]. Currently in Morocco, salinity affects about 350,000 ha of arable lands [6]. The Tadla plain is one of the main agricultural zones in Morocco affected 
by salinity, with an arable land of $259,600 \mathrm{Ha}$, of which $49 \%$ is irrigated. Poor management of irrigation and misuse of chemical fertilizers are the main causes of soil salinization in this area. Soil salinity distribution is variable in the Tadla perimeter, with an average of $2.76 \mathrm{dS} \cdot \mathrm{m}^{-1}$ [7]. The Beni Amir irrigated district is the most affected by salinity, with maximum values of electrical conductivity (EC) equal to $8.4 \mathrm{dS} \cdot \mathrm{m}^{-1}$.

Salt stress negatively affects plant growth and productivity due to osmotic and ion stress [8,9]. Salinity can drastically affect many plant morphophysiological functions by disrupting cytoplasmic ionic concentration and osmotic gradients inhibiting several vital metabolic and physiological functions, such as the reduction of photosynthetic activity [10], reduction of protein synthesis and enzymatic activity [11,12], and disruption of nutritional balance by reducing the absorption of essential elements such as N, P, K, and Ca [13,14].

One of the important strategies to cope with the adverse effects of salinity on plants is the adoption of adequate fertilization management practices [15]. Phosphorus fertilization is an important growth-limiting factor for most crops, particularly for crops cultivated under salinity conditions $[16,17]$. Increased phosphorus fertilization is one of the judicious and practical solutions that can be used to cope with salinity stress when using brackish and saline water for irrigation [18]. Phosphorus has always been recognized as a key nutrient for root development [19]. It was found that P fertilization improved plant root growth and development under drought conditions [20], which means that the same effect on root development may improve crop tolerance and growth under saline conditions. Contrarily, it was found that high external $\mathrm{P}$ application increased sodium assimilation and consequently reduced the salt tolerance of soybean [21]. Increasing phosphorus application has been found to either increase or decrease the salt tolerance of several crops depending on their threshold of salinity tolerance [22-24]. Moreover, it has been shown in field studies that the P fertilization of barley and wheat plants grown under saline conditions increased their salt tolerance and, therefore, their productivity [25]. The significant positive role of $\mathrm{P}$ in reducing salinity's impacts on plant growth, productivity, and nutrient uptake has been reported. The ability of $\mathrm{P}$ to strengthen plant metabolism such as sugar accumulation and synthesis, energy storage and transfer, cell division, and enlargement plays a significant role in avoiding damages caused by salinity stress. Although increased $\mathrm{P}$ reduces the uptake of toxic ions such as $\mathrm{Na}$, there still might be a specific mechanism of $\mathrm{P}$ in the nutrient balance that helps plants to avoid salinity damages [18].

Sugar beets (Beta vulgaris L.) are considered among rustic and resilient crops that can be grown under a wide range of pedoclimatic conditions [26]. Sugar beet is recognized as a salt-tolerant crop, with an EC threshold equal to $7.0 \mathrm{dS} \cdot \mathrm{m}^{-1}$ [27]. Sugar beet employs two mechanisms for tolerance to salinity: compartmentalization of $\mathrm{Na}+$ ions in vacuoles ( $\mathrm{Na}+$ ion in high concentrations is generally toxic to plants) and osmotic adjustment accumulating compatible osmolytes in high concentrations in the cytoplasm [28]. They contribute to around $20 \%$ of total sugar production worldwide [29]. In Morocco, sugar beet is considered a major winter crop occupying a total area of 65,000 ha (in the 2019/2020 cropping season), including 17,000 ha in the Tadla region. Being a drought- and salt-tolerant crop, and due to its high productivity, sugar beet is considered a good cash crop in Morocco. Freshwater has become a scarce resource in Morocco, and its low availability is a major constraint for crop production in Morocco. Alternatively, the use of saline water for irrigation is expanding and has become a necessity. Sugar beet is recognized as a salt-tolerant crop, with an EC threshold equal to $7.0 \mathrm{dS} \cdot \mathrm{m}^{-1}$ [28]. Sugar beet employs two mechanisms for tolerance to salinity: compartmentalization of $\mathrm{Na}^{+}$ions in vacuoles $\left(\mathrm{Na}^{+}\right.$ion in high concentrations is generally toxic to plants) and osmotic adjustment accumulating compatible osmolytes in high concentration in the cytoplasm [29].

The aim of this study was to investigate and evaluate the combined effects of salinity and phosphorus supply on sugar beet's growth, productivity, and sugar content. 


\section{Materials and Methods}

\subsection{Experimental Site}

This research was conducted between December 2018 and July 2020 at an experimental farm of the National Institute of Agronomic Research (INRA) in Tadla, Morocco $\left(X=32.2^{\circ}\right.$; $\mathrm{Y}=6.31^{\prime} ; \mathrm{Z}=450 \mathrm{~m}$ ). The soil was classified as Chromic Luvisols [30]. The climate is arid with an irregular rainfall averaging $278 \mathrm{~mm}$. The average temperature is $18{ }^{\circ} \mathrm{C}$, with a maximum in August that often exceeds $35^{\circ} \mathrm{C}$ and a minimum in January of approximately $0{ }^{\circ} \mathrm{C}$ (Figure 1).

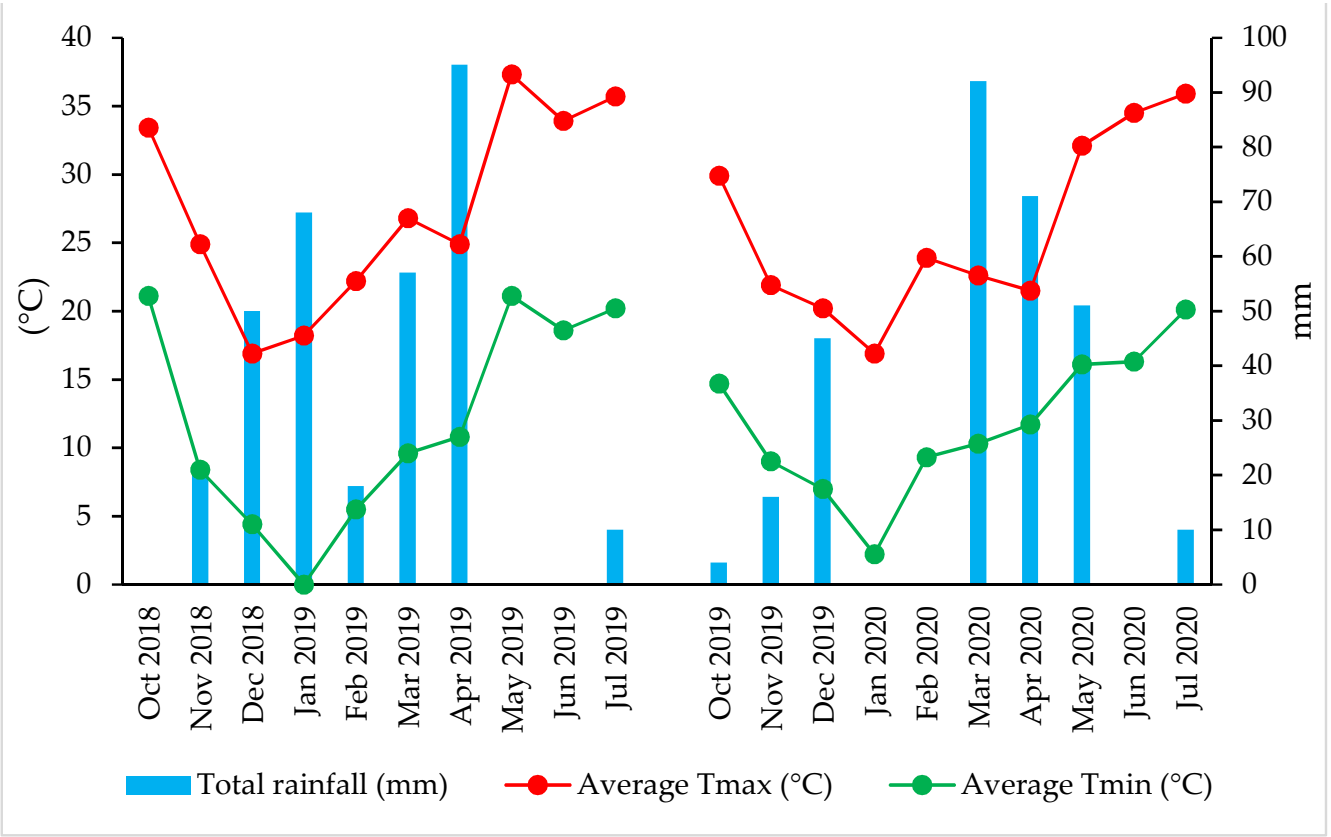

Figure 1. Variation of temperature and rainfall during the 2018-2019 and 2019-2020 seasons.

\subsection{Trial Set-Up}

The field experiment was conducted in a split-plot design with three replicates applying four irrigation water salinity levels and three $P$ fertilization rates. The tested salinity levels were freshwater with an EC value of $0.7 \mathrm{dS} \cdot \mathrm{m}^{-1}$ and two levels of saline water with an EC value of 4 and $8 \mathrm{dS} \cdot \mathrm{m}^{-1}$ in the 2018-2019 season and freshwater with an EC value of $0.7 \mathrm{dS} \cdot \mathrm{m}^{-1}$ with three levels of saline water with an EC value of 4,8 , and $12 \mathrm{dS} \cdot \mathrm{m}^{-1}$ in the 2019-2012 season. The high-salinity treatment of $12 \mathrm{dS} \cdot \mathrm{m}^{-1}$ was added in the second season to evaluate the sugar beet responses to a high salinity level beyond its tolerance threshold $\left(7-8 \mathrm{dS} \cdot \mathrm{m}^{-1}\right)$. Salinity levels were achieved by adding salt $(\mathrm{NaCl})$ to freshwater. The $\mathrm{P}$ fertilization rate consisted of 100 (recommended dose used by farmers), 120, and $140 \mathrm{~kg} \mathrm{P} \mathrm{O}_{5} \cdot \mathrm{ha}^{-1}$. The area of each plot was $20 \mathrm{~m}^{2}(4 \mathrm{~m} \times 5 \mathrm{~m})$, and each consisted of six rows with a $50 \mathrm{~cm}$ interline. P was supplied under the form of triple superphosphate $(45 \%$ of $\mathrm{P}_{2} \mathrm{O}_{5}$ ), which is commonly used in the region. Phosphorus fertilizer was incorporated into the soil before sowing. The tested variety of sugar beet was "Sporta", which was shown to be a salt-tolerant variety.

Other fertilizer requirements were applied equally for all treatments through fertigation with a drip irrigation system. Irrigation with saline water started 60 days after planting, and the crop was irrigated daily until harvest (1 June 2020) following the evapotranspiration method (ET0). Sugar beet was sown in December 2018 and harvested on 1 July 2019 for the first season, while in the second season, it was sown on 31 October 2019 and harvested on 1 June 2020. The recommended seed rate of 100,000 seeds per ha for sugar beets was used. Thinning of plants (two per hole) was performed before the treatment application. During preparation and plant growth, the soil was supplemented with ammonium sulfate using a rate of $200 \mathrm{~kg} \cdot \mathrm{ha}^{-1}$ of nitrogen. 


\subsection{Physical and Chemical Analysis}

Before sowing, the physical and chemical soil characteristics of two soil depths were determined according to Jackson [31]. The soil analysis results are reported in Table 1. The electrical conductivity of the soil was measured using the soil-saturated paste method with an EC meter (HI 9812, Hanna Instruments, Casablanca, Morocco). The ECe values were relatively low, which classed the soils as being nonsaline [32].

Table 1. Soil physicochemical properties.

\begin{tabular}{|c|c|c|c|c|c|c|c|}
\hline Soil Depth & \multicolumn{2}{|c|}{ pH 1:2.5 } & \multirow{2}{*}{$\frac{E C}{d S \cdot m^{-1}}$} & \multirow{2}{*}{$\begin{array}{c}\text { Organic Matter } \\
\% \%\end{array}$} & \multirow{2}{*}{$\begin{array}{c}\text { Total N (Kjeldahl) } \\
\text { g/kg }\end{array}$} & \multirow{2}{*}{$\frac{\mathrm{P}_{2} \mathrm{O}_{5}(\text { Olsen })}{\mathrm{mg} \cdot \mathrm{kg}^{-1}}$} & \multirow{2}{*}{$\frac{\mathrm{K}_{2} \mathrm{O} \text { (Acetate of } \mathrm{Na} \text { ) }}{\mathrm{mg} \cdot \mathrm{kg}^{-1}}$} \\
\hline $\mathrm{cm}$ & Water & $\mathrm{KCl}$ & & & & & \\
\hline $0-20$ & 8.24 & 7.36 & 0.1 & 1.45 & 2.34 & 43 & 459 \\
\hline $20-40$ & 8.38 & 7.24 & 0.22 & 0.59 & 3.44 & 22 & 405 \\
\hline
\end{tabular}

\subsection{Yield Parameters}

Sugar beet root yield was measured at harvest using the whole plot area $\left(\mathrm{m}^{2}\right)$ and then extrapolated to $t \cdot h a^{-1}$. Yield components, including root weight, length, and diameter, were determined using values from four plants per plot.

\subsection{Sugar Content Determination}

Sugar content (\% pol) was determined using the procedure described by Reinefeld et al. [33].

\subsection{Stomatal Conductance Measurements}

Stomatal conductance was measured using the SC-1 Leaf Porometer (Decagon Devices, Inc., Pullman, WA, USA). The stomatal conductance was determined between 10 a.m. and 12 p.m. on the upper leaf surface well exposed to sunlight. Three measurements per plant were carried out for four plants per plot once for each season.

\subsection{Statistical Analysis}

Statistical analysis was carried out using SPSS 17.0 software. A two-way analysis of variance (ANOVA) was used to assess the effects of both salinity and phosphorus on monitored parameters. The level of significance was set to $p<0.05$.

For each analysis, when ANOVA was significant, statistically significant differences between means were identified using Tukey's test $(p \leq 0.05)$.

\section{Results}

\subsection{Growth Parameters}

Figure 2 presents the obtained average results recorded in both seasons in terms of final growth parameters, including fresh root weight per plant, root length, root width, number of leaves per plant, leaf area, and fresh weight of leaves per plant subjected to the combined effect of both salinity and $\mathrm{P}$ application. It is obvious that salinity negatively affected most investigated parameters $(p<0.05)$, except the root length, where there was no significant difference between salinity levels, and the number of leaves per plant, where the highest level of salinity resulted in increased leaves number but with a lower leaf area. However, $P$ application differently affected the investigated parameters depending on the salinity level. For instance, P application negatively affected $(p<0.05)$ all investigated parameters except for root length under control conditions, where a P application of $140 \mathrm{~kg} \cdot \mathrm{ha}^{-1}$ significantly increased this parameter. 


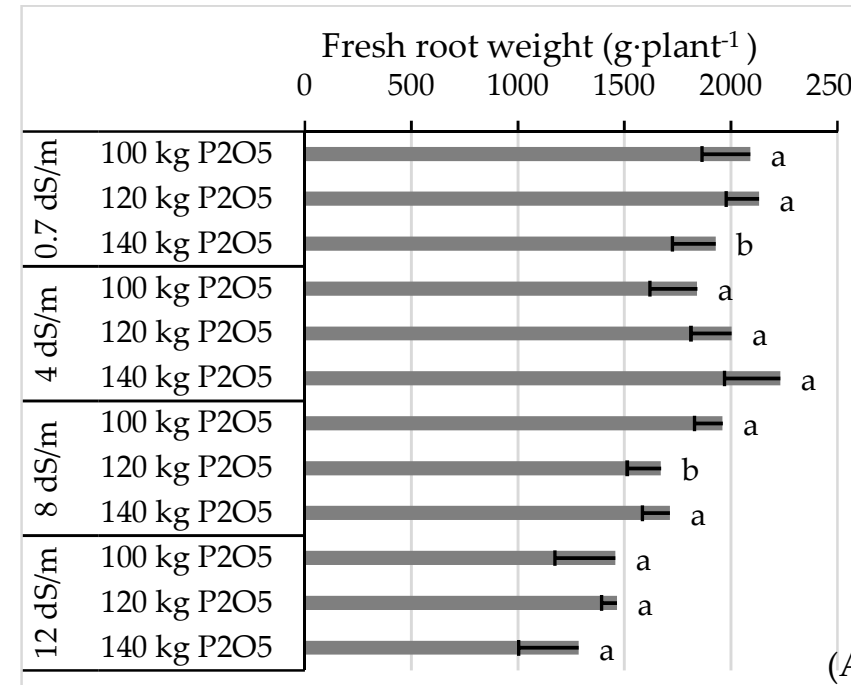

(A)

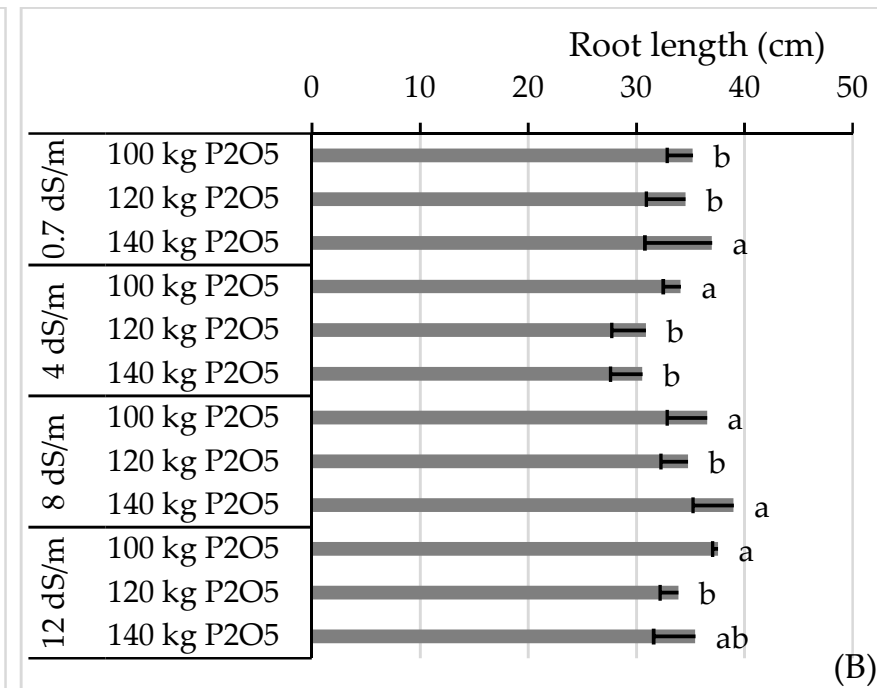

Number of leaves $\begin{array}{llllllllll}0 & 10 & 20 & 30 & 40 & 50 & 60 & 70 & 80 & 90\end{array}$

\begin{tabular}{|c|c|c|}
\hline \\
\hline \multicolumn{3}{|c|}{$\begin{array}{ll}g & 100 \mathrm{~kg} \text { P2O5 } \\
\text { क्र } & 120 \mathrm{~kg} \mathrm{P2O} 5\end{array}$} \\
\hline & $140 \mathrm{~kg}$ P2O5 & $\models \mathrm{b}$ \\
\hline$\xi$ & $100 \mathrm{~kg}$ P2O5 & $=\mathrm{a}$ \\
\hline$\frac{5}{8}$ & $120 \mathrm{~kg}$ P2O5 & a \\
\hline & $140 \mathrm{~kg}$ P2O5 & a \\
\hline$\xi$ & $100 \mathrm{~kg}$ P2O5 & \\
\hline $\begin{array}{l}\bar{n} \\
\infty \\
\infty\end{array}$ & $\begin{array}{l}120 \mathrm{~kg} \text { P2O5 } \\
140 \mathrm{~kg} \text { P2O5 }\end{array}$ & \\
\hline $\bar{q}$ & $100 \mathrm{~kg}$ P2O5 & $F a$ \\
\hline$\frac{\pi}{0}$ & $120 \mathrm{~kg}$ P2O5 & $F a$ \\
\hline & $140 \mathrm{~kg}$ P2O5 & $\mapsto$ \\
\hline
\end{tabular}

Leaf area $\left(\mathrm{cm}^{2} \cdot\right.$ plant $\left.^{-1}\right)$

01000200030004000500060007000

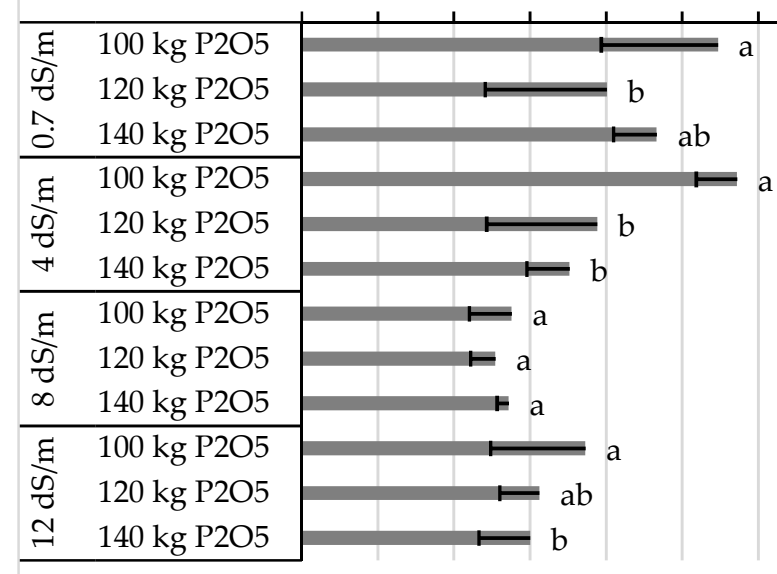

(E)

(C)

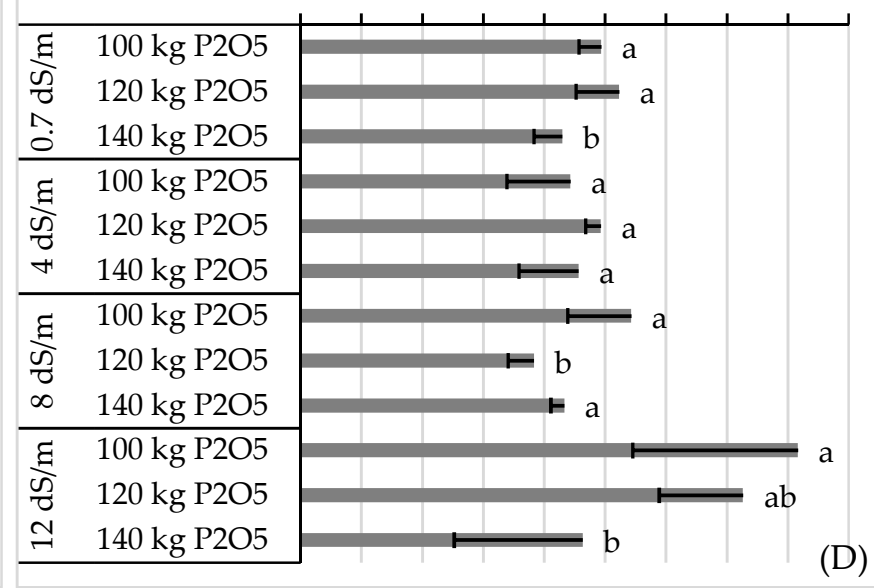

Fresh weight of leaves per plant $\left(\mathrm{g} \cdot \mathrm{plant}^{-1}\right)$

$\begin{array}{llllllll}0 & 200 & 400 & 600 & 800 & 1000 & 1200 & 1400\end{array}$

Figure 2. Final growth parameters, including fresh root weight per plant (A), root length (B), root width (C), number of leaves per plant (D), leaf area (E), and fresh weight of leaves per plant (F). Error bars indicate the standard deviation. Phosphorus treatments under the same salinity level without a common letter are significantly different at $p<0.05$. 


\subsection{Sugar Beet Yield}

Statistical analysis indicated that the irrigation water salinity had a highly significant effect on the root yield in both seasons $(p<0.01)$, but the interaction between salinity and phosphorus was not significant (Figure 3). During the 2018-2019 season, salinity significantly reduced $(p=0.003$ ) the root yield by $21 \%$ and by $26 \%$ under saline irrigation with an EC value equal to 4 and $8 \mathrm{dS} \cdot \mathrm{m}^{-1}$, respectively, compared to the control. Sugar beet yield responded positively to an additional supply of $P$ fertilization under freshwater conditions and increased by $11 \%$ and $17 \%$ under a P application rate of 120 and $140 \mathrm{~kg} \cdot \mathrm{ha}^{-1}$ of $\mathrm{P}_{2} \mathrm{O}_{5}$, respectively, compared to the control $\left(100 \mathrm{~kg} \cdot \mathrm{ha}^{-1}\right.$ of $\left.\mathrm{P}_{2} \mathrm{O}_{5}\right)$. Similar results were recorded at low salinity $\left(\mathrm{ECW}=4 \mathrm{dS} \cdot \mathrm{m}^{-1}\right)$. The addition of phosphorus supply using a rate equal to 120 and $140 \mathrm{~kg} \cdot \mathrm{ha}^{-1}$ of $\mathrm{P}_{2} \mathrm{O}_{5}$ increased the yield by $8 \%$ and $7.5 \%$, respectively. At high salinity $\left(8 \mathrm{dS} \cdot \mathrm{m}^{-1}\right)$, only a $\mathrm{P}$ application of $120 \mathrm{~kg} \cdot \mathrm{ha}^{-1}$ of $\mathrm{P}_{2} \mathrm{O}_{5}$ increased the root yield of sugar beets by $7.5 \%$, which indicates that the optimal phosphorus application for sugar beets under high salinity should not exceed $120 \mathrm{~kg} \cdot \mathrm{ha}{ }^{-1}$ of $\mathrm{P}_{2} \mathrm{O}_{5}$.

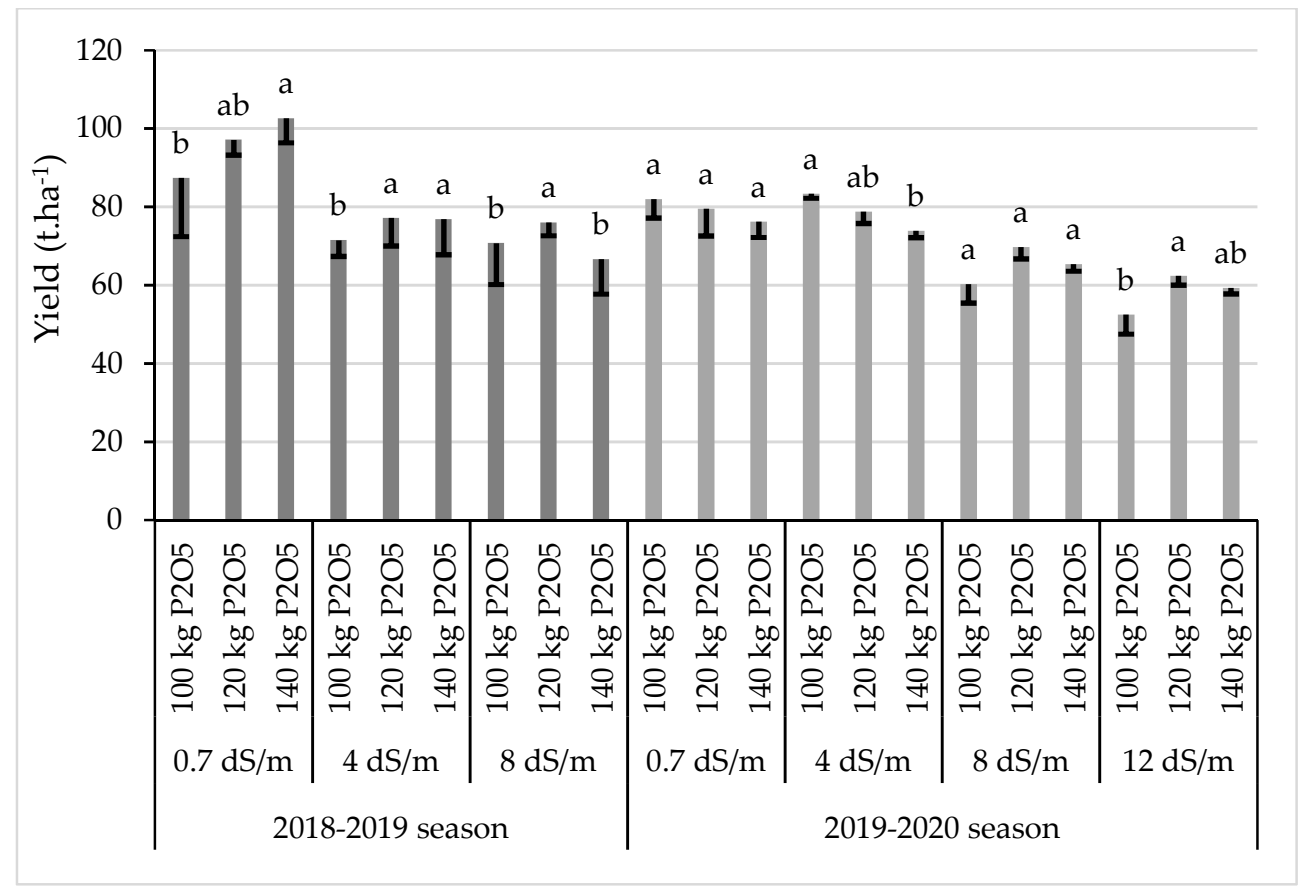

Figure 3. Sugar beet yield as affected by salinity and P application for both seasons (2018-2019 and 2019-2020). Error bars indicate the standard deviation. Phosphorus treatments under the same salinity level without a common letter are significantly different at $p<0.05$.

During the second growing season (2019-2020), the salinity significantly reduced $(p=0.002)$ the root yield by $1 \%, 19 \%$, and $27 \%$ under saline irrigation with an EC value equal to 4 and 8 and $12 \mathrm{dS} \cdot \mathrm{m}^{-1}$, respectively, compared to the control $\left(0.7 \mathrm{dS} \cdot \mathrm{m}^{-1}\right)$. Under a high salinity level $\left(12 \mathrm{dS} \cdot \mathrm{m}^{-1}\right)$, the phosphorus supply significantly increased $(p=0.04)$ the yield of sugar beets by 19 and $13 \%$ under a P application rate of 120 and $140 \mathrm{~kg} \cdot \mathrm{ha}^{-1}$ of $\mathrm{P}_{2} \mathrm{O}_{5}$, respectively, compared to the control $\left(100 \mathrm{~kg} \cdot \mathrm{ha}^{-1}\right.$ of $\left.\mathrm{P}_{2} \mathrm{O}_{5}\right)$.

\subsection{Sugar Content of the Roots}

Figure 4 shows the variation of the total sugar content of sugar beet under both salinity and P fertilization. During the first growing season (2018-2019), total sugar content was significantly increased by $5 \%$ and $7 \%$ under saline irrigation with an EC value of 4 and $8 \mathrm{dS} \cdot \mathrm{m}^{-1}$, respectively, as compared with the control $(p=0.04)$. However, in the second growing season (2019-2020), only the highest level of saline water $\left(E C=12 \mathrm{dS} \cdot \mathrm{m}^{-1}\right)$ significantly increased the sugar content by $15 \%$ compared to the control. 


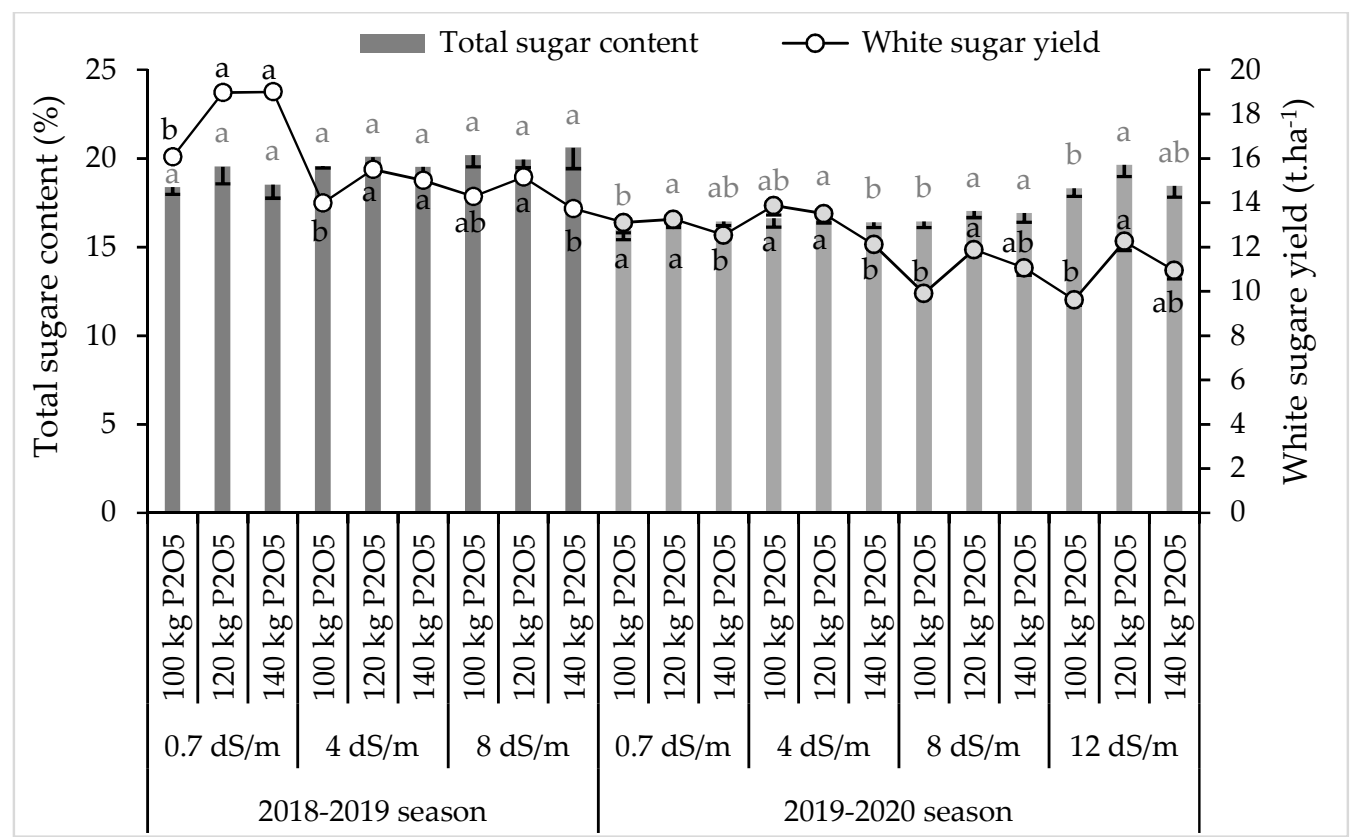

Figure 4. Variation of total sugar content and white sugar yield under different salinity levels and P applications. Error bars indicate the standard deviation. Phosphorus treatments under the same salinity level without a common letter are significantly different at $p<0.05$.

During the 2018-2019 season, P application had no effect on total sugar content ( $p=0.4$ ), while in the 2019-2020 season, the sugar beet plants were able to produce more sugar content in their roots. In fact, increased $\mathrm{P}$ application significantly improved $(p>0.05)$ the sugar content compared to the control $\left(100 \mathrm{~kg}\right.$ of $\left.\mathrm{P}_{2} \mathrm{O}_{5} \cdot \mathrm{ha}^{-1}\right)$ under all tested salinity levels, and a maximum sugar content was observed for all salinity treatments under $120 \mathrm{~kg}$ of $\mathrm{P}_{2} \mathrm{O}_{5} \cdot \mathrm{ha}^{-1}$.

White sugar yield (root yield $\times$ total sugar content) was also significantly affected by salinity level $(p<0.01)$. In fact, in the 2018-2019 season, it was reduced by 18 and $20 \%$ under 4 and $8 \mathrm{dS} \cdot \mathrm{m}^{-1}$, respectively, compared to the control, while in the 2019-2020 season, white sugar yield increased by $2 \%$ under $4 \mathrm{dS} \cdot \mathrm{m}^{-1}$ and reduced by $16 \%$ under both 8 and $12 \mathrm{dS} \cdot \mathrm{m}^{-1}$. Regarding the $\mathrm{P}$ application effect on white sugar yield, a rate of $120 \mathrm{~kg}$ of $\mathrm{P}_{2} \mathrm{O}_{5} \cdot \mathrm{ha}^{-1}$ provided the highest yield under all salinity levels in both growing seasons.

\subsection{Stomatal Conductance}

Average data of stomatal conductance of both seasons are shown in Figure 5. The stomatal conductance significantly decreased under salinity conditions $(p<0.01)$. However, the phosphorus tended to increase the stomatal conductance of sugar beets, especially under saline irrigation, with an EC value equal to 4 and $12 \mathrm{dS} \cdot \mathrm{m}^{-1}$, while $\mathrm{P}$ application had no effect under irrigation with an EC value equal to 0.7 and $8 \mathrm{dS} \cdot \mathrm{m}^{-1}$. 


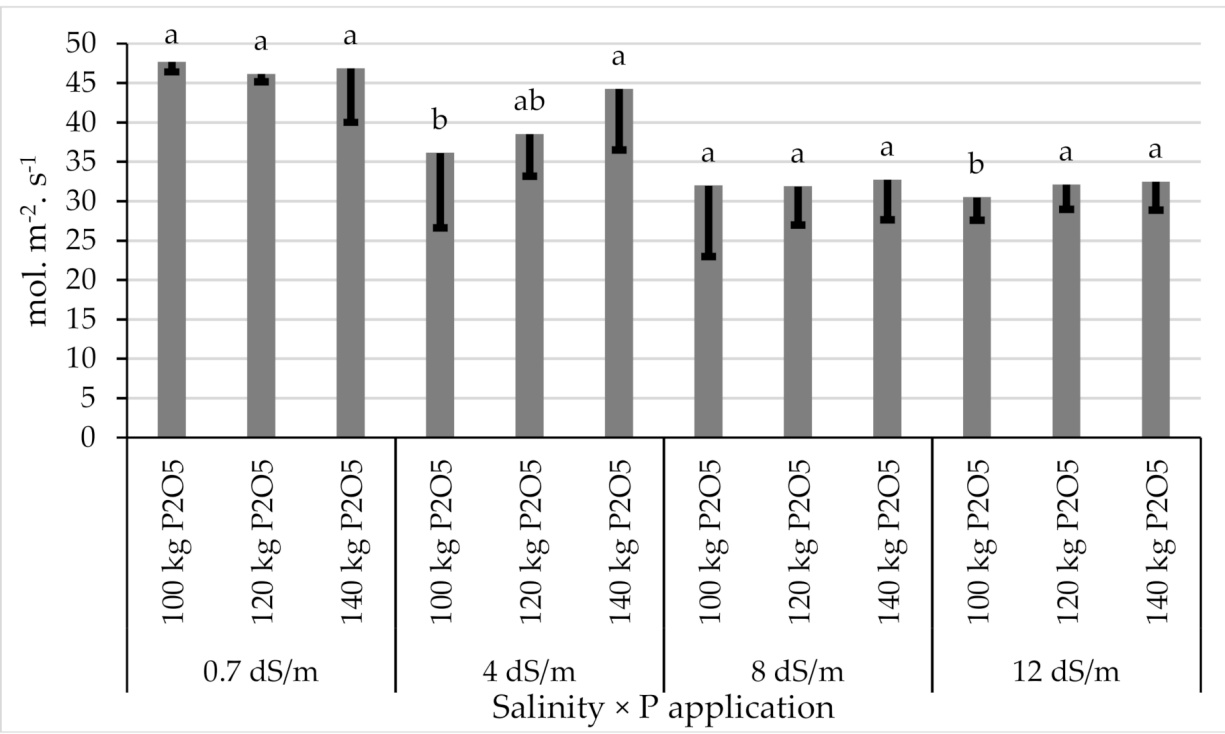

Figure 5. Variation of stomatal conductance under different salinity levels and P application. Error bars indicate the standard deviation. Phosphorus treatments under the same salinity level without a common letter are significantly different at $p<0.05$.

\section{Discussion}

Sugar beet (Beta vulgaris L.) is known to be a salt-tolerant crop. Its salt-tolerance threshold was reported to be between 7 and $9 \mathrm{dS} \cdot \mathrm{m}^{-1}[34,35]$, and it can be grown under moderately saline conditions [36]. It is highly salt-tolerant during vegetative growth [37]. Plant species have variable responses to salinity in terms of their growth and productivity. Crop and forage species can be classified according to their salt tolerance (or sensitivity) based on two parameters: the threshold $\mathrm{ECW}$ and the slope, i.e., percentage of yield reduction per unit of ECW. The ECw threshold is defined as the salinity level that does not significantly reduce the yield and at which the yield starts to decrease. According to this approach, sugar beet was classified as a salt-tolerant species, with an EC threshold of $7.0 \mathrm{dS} \cdot \mathrm{m}^{-1}$ [28]. Moreover, it is well documented that various genotypes respond differently to salt stress, which means that the EC threshold can be less or more than $7 \mathrm{dS} \cdot \mathrm{m}^{-1}[38,39]$.

In this study, we investigated the combined effect of salinity and P fertilization on the growth and productivity of sugar beet. In this study, salinity reduced most growth and productivity parameters, which can be explained by the inhibition of photosynthetic activity, sugar synthesis and translocation, and cell elongation [9]. Our findings clearly indicate that salinity reduced the fresh root weight, root length, leaf area, and fresh weight of leaves, while it increased the number of leaves per plant. Similar results were obtained by Ghoulam et al. [40], who found that an increased $\mathrm{Na}^{+}$concentration led to a great reduction in growth parameters such as leaf area and leaf and root weight, while the leaf number was less affected by the increased salinity level; therefore, it seems that the reduction of leaf area and keeping the same number of leaves is one of the adaptation strategies adopted by sugar beet to cope with salinity stress. Jamil et al. [38] also showed that salinity significantly reduced the leaf area of sugar beet.

The findings of this study indicate that irrigation water salinity had a significant effect on the root yield of sugar beets. The obtained data from the first season (2018-2019) show that salinity significantly decreased the root yield by $21 \%$ and $26 \%$ under saline irrigation, with an EC value equal to 4 and $8 \mathrm{dS} \cdot \mathrm{m}^{-1}$, respectively, compared to the control. The results are similar to the findings of Zaki et al. [41] and Khafagi and El-Lawandy [42], who reported that soil salinity may lead to a reduction in terms of sugar beet yield. Moreover, it has been confirmed that salinity significantly reduces root and shoot growth, as well as biomass accumulation [43]. Our results are in agreement with those recorded by Eid and 
Ibrahim [44], who reported that irrigating sugar beet crops with drainage water with an EC value equal to $3.8 \mathrm{dS} \cdot \mathrm{m}^{-1}$ reduced root and sugar yield by about $21 \%$ and $42 \%$ compared to freshwater $\left(0.5 \mathrm{dS} \cdot \mathrm{m}^{-1}\right)$.

Our findings are also in line with the previous findings of Zaki et al. [41], who reported that sugar yield is reduced due to absorbed $\mathrm{Na}^{+}$ions. Similarly, it was demonstrated by Çimrin et al. [45] that salinity stress reduced root and shoot biomass accumulation. The negative effect of salinity on root yield is probably due to the osmotic inhibition of water absorption due to the high salt concentration in the soil, the accumulation of certain ions such as $\mathrm{Na}^{+}$and $\mathrm{Cl}^{-}$in high concentrations in plant cells, the disruption of the mineral balance of plants [42], or the reduction in photosynthetic activity and carbohydrate metabolism [43]. The reduction in beet yield was possibly due to reduced water and nutrient uptake under a high-salinity environment [46]. Contrarily, it was reported by Moreno et al. [34] that beet and sugar yields were significantly increased under irrigation with saline water $\left(5.9-7.0 \mathrm{dS} \cdot \mathrm{m}^{-1}\right)$ compared to non saline irrigation $\left(1.7 \mathrm{dS} \cdot \mathrm{m}^{-1}\right)$. Another study also found that the root weight of some cultivars of sugar beet plants increased with a mild level of water salinity $\left(E C=5.5 \mathrm{dS} \cdot \mathrm{m}^{-1}\right)$ [47]. Contrarily, Feizi et al. [48] reported that the irrigation water salinity with an EC value up to $12.3 \mathrm{dS} \cdot \mathrm{m}^{-1}$ had no significant effect on the root yield of sugar beets.

Regarding the $\mathrm{P}$ fertilization effect on sugar beet yield, our finding suggests that under salinity, a P fertilization rate of $120 \mathrm{~kg}$ of $\mathrm{P}_{2} \mathrm{O}_{5} \cdot \mathrm{ha}^{-1}$ resulted in a yield increase. In fact, it is well known that $\mathrm{P}$ fertilization improves crop yield under salinity conditions. For instance, Hussain et al. [49] reported that the addition of 60 and $120 \mathrm{~kg}$ of $\mathrm{P}_{2} \mathrm{O}_{5} \cdot \mathrm{ha}^{-1}$ increased sugar beet yield under salinity $\left(3 \mathrm{dS} \cdot \mathrm{m}^{-1}\right)$ by 37 and $47 \%$ over control $\left(0 \mathrm{~kg}\right.$ of $\left.\mathrm{P}_{2} \mathrm{O}_{5} \cdot \mathrm{ha}^{-1}\right)$. In another study conducted by Khan et al. [50], it was reported that increasing rates of $P$ fertilization increased root, sugar yields, and root sucrose content. El-Tilib et al. [51] reported that $P$ fertilization resulted in a significant increase in cane and sugar yields. Bargaz et al. [52] suggested adequate $P$ fertilization under salinity conditions is likely a promising strategy to improve salinity tolerance and productivity of $P$. vulgaris, a response relationship that seems to be P-rate dependent.

An increase in sugar content was observed due to increased irrigation water salinity. In fact, during the first season (2018-2019), this parameter increased by about 5 and 7\% under saline irrigation with an EC value equal to 4 and $8 \mathrm{dS} \cdot \mathrm{m}^{-1}$, respectively, compared to the control. Our results are well aligned with those reported by Hajiboland et al. [47], who showed that salinity increased the sugar content in sugar beets. Moreover, it was reported by Abdel-Mawly and Zanouny [53] that total soluble sugar (TSS) in the root of sugar beets increased with an increasing level of irrigation water salinity. The increase in TSS may be due to more salt absorption by plants under increased salinity levels, which consequently decreases purity and negatively affects the refinable sugar percentage. The increase in sugar content is mainly explained by the osmotic adjustment phenomenon to maintain equilibrium between the vacuole and cell cytoplasm to allow water uptake. In fact, plants accumulate compatible solutes such as soluble sugars in the cell cytoplasm to cope with salt-induced water stress [54]. In some plants, in response to salt stress, the accumulation of sugars is considered an important mechanism in osmotic adjustment [55]. An efficient accumulation of sugar in the sugar beet roots is linked to the effect of plant growth regulators in the anatomy modification of storage roots with increasing effects on sucrose concentration [56]. However, it was reported by El-Maghraby et al. [57] and Khalil et al. [58] that sucrose, TSS, and the purity of sugar beet juice increased with increasing K levels but reduced due to salinity stress.

The obtained results regarding sugar content show that sugar beet plants were able to produce more sugar content in their roots under phosphorus supply at all salinity levels, including the control. On other hand, it was reported by Shahriaripour et al. [59] that sugar content in pistachio seedlings was reduced by applying phosphorus.

The stomatal conductance was significantly reduced under saline irrigation. However, phosphorus tends to increase the stomatal conductance of sugar beets under EC 4 and 
$12 \mathrm{dS} \cdot \mathrm{m}^{-1}$, but this effect is not significant. Katerii et al. [29] reported that the stomatal conductance of sugar beet was negatively affected by increased salinity, and sugar beet cultivated under saline conditions was able to maintain production under severe water stress. Furthermore, the evapotranspiration and yield of sugar beet were slightly decreased due to salinity because of the slight reduction in leaf area and the maintenance of photosynthetic activity under saline conditions. The finding of an experiment carried out by Dadkhah [60], who investigated the effect of several salinity levels reaching $350 \mathrm{mM}$ of $\mathrm{NaCl}$ in sugar beet, suggested that net photosynthesis and stomatal conductance (gs) were greatly and negatively affected by increased salinity, whereas leaves from plants exposed to $50 \mathrm{mM}$ salinity showed little change in photosynthesis, whereas the photosynthetic rates of leaves treated by high levels of salinity had up to a $91.5 \%$ reduction with an increase in the $\mathrm{CO}_{2}$ compensation point. Regarding other species, it was reported by Zribi et al. [61] that pepper's stomatal conductance was significantly reduced under the effect of salt stress. These results agree with those obtained with peppers [37] and tomatoes [62], which reported that salinity can inhibit and reduce net photosynthesis and stomatal conductance due to a decline of the $\mathrm{CO}_{2}$ supply, resulting from the partial closure of the stomata either by disrupting the biochemical mechanism of $\mathrm{CO}_{2}$ fixation or by both mechanisms.

\section{Conclusions}

The findings of our study reveal that the irrigation water salinity increment led to significant reductions in the sugar beet growth, yield, root weight, and white sugar yield. However, the sugar content was improved under increased salinity. On the other hand, $\mathrm{P}$ fertilization was shown to improve sugar yield and content as well as stomatal conductance under most of the salinity conditions tested. Therefore, the phosphorus supply can reduce the adverse effects of high salinity on plant growth and physiological development. In light of the results obtained, $\mathrm{P}$ fertilization could be one of the best practices to enhance sugar beets' tolerance of salinity. Thus, to obtain a maximum root and sugar yield under saline water, application of a phosphorus dose of $120 \mathrm{~kg}$ of P2O5.ha ${ }^{-1}$ may be recommended.

Author Contributions: Conceptualization, R.C.-A. and A.B.; methodology, H.B.; software, H.B.; validation, B.B., R.C.-A. and A.B.; formal analysis, H.B.; investigation, B.H and B.B.; resources, R.C.-A. and B.B.; data curation, A.H.; writing—original draft preparation, B.H and A.H.; writing-review and editing, A.H., R.C.-A. and A.B.; visualization, A.H. and H.B.; supervision, R.C.-A. and A.B. and B.B.; project administration, R.C.-A.; funding acquisition, R.C.-A. All authors have read and agreed to the published version of the manuscript.

Funding: This research was funded by the OCP Foundation in AppHos Project AGR-CHO-01/2017.

Data Availability Statement: Not applicable.

Acknowledgments: The authors thank the OCP Foundation for scientific financial research support and the National Institute for Agronomic Research of Tadla Morocco (INRA) for supporting this study and providing research facilities. We also thank Cosumar Groupe for technical assistance in analyzing the sugar beet composition.

Conflicts of Interest: The authors declare no conflict of interest.

\section{References}

1. Tester, M.; Davenport, R. Na+ tolerance and Na+ transport in higher plants. Ann. Bot. 2003, 91, 503-527. [CrossRef]

2. Ashraf, M.; Foolad, M.R. Roles of glycine betaine and proline in improving plant abiotic stress resistance. Environ. Exp. Bot. 2007, 59, 206-216. [CrossRef]

3. Liang, W.; Ma, X.; Wan, P.; Liu, L. Plant salt-tolerance mechanism: A review. Biochem. Biophys. Res. Commun. 2018, 495, $286-291$. [CrossRef] [PubMed]

4. Jamil, A.; Riaz, S.; Ashraf, M.; Foolad, M.R. Gene expression profiling of plants under salt stress. Crit. Rev. Plant Sci. 2011, 30, 435-458. [CrossRef]

5. Sakadevan, K.; Nguyen, M.L. Rational utilization of salt affected soils and saline waters for crop production and the protection of soil and water in agricultural catchments. Soil Newsl. 2011, 43, 7-8. 
6. Badraoui, M.; Agbani, M.; Soudi, B. Evolution de la qualité des sols sous mise en valeur intensive au Maroc. Sémin. Intensif. Agric. Qual. Sols Eaux' Rabat Maroc 2000, 1-9. Available online: https://agrimaroc.net/intensificationagricole/03-badraoui.pdf (accessed on 20 January 2021).

7. ORMVAT Office Régionale de Mise En Valeur Agricole de Tadla Morocco. Suivi des Paramètres Environnementaux' Campagne Fin d'Été 2019. Available online: https: / / ormva-tadla.ma/filieres / production-v\%C3\%A9g\%C3\%A9tale (accessed on 20 January 2021)

8. Kachout, S.; Mansoura, A.B.; Jaffel, K.; Leclerc, J.C.; Rejeb, M.N.; Ouerghi, Z. the effect of salinity on the growth of the halophyte Atriplex hortensis (Chenopodiaceae). Appl. Ecol. Environ. Res. 2009, 7, 319-332. [CrossRef]

9. Parida, A.K.; Das, A.B. Salt tolerance and salinity effects on plants: A review. Ecotoxicol. Environ. Saf. 2005, 60, 324-349. [CrossRef] [PubMed]

10. El-Hendawy, S.E.; Hu, Y.; Yakout, G.M.; Awad, A.M.; Hafiz, S.E.; Schmidhalter, U. Evaluating salt tolerance of wheat genotypes using multiple parameters. Eur. J. Agron. 2005, 22, 243-253. [CrossRef]

11. Liang, Y.; Si, J.; Nikolic, M.; Peng, Y.; Chen, W.; Jiang, Y. Organic manure stimulates biological activity and barley growth in soil subject to secondary salinization. Soil Biol. Biochem. 2005, 37, 1185-1195. [CrossRef]

12. Sadak, M.S.; Abdelhamid, M.T. Influence of amino acids mixture application on some biochemical aspects, antioxidant enzymes and endogenous polyamines of Vicia faba plant grown under seawater salinity stress. Gesunde Pflanz. 2015, 67, 119-129. [CrossRef]

13. $\mathrm{Hu}, \mathrm{Y}$;; Fricke, W.; Schmidhalter, U. Salinity and the growth of non-halophytic grass leaves: The role of mineral nutrient distribution. Funct. Plant Biol. 2005, 32, 973-985. [CrossRef] [PubMed]

14. Abdelhamid, M.T.; Shokr, M.M.; Bekheta, M.A. Growth, root characteristics, and leaf nutrients accumulation of four Faba bean (Vicia faba L.) cultivars differing in their broomrape tolerance and the soil properties in relation to salinity. Commun. Soil Sci. Plant Anal. 2010, 41, 2713-2728. [CrossRef]

15. Colla, G.; Rouphael, Y.; Cardarelli, M.; Tullio, M.; Rivera, C.M.; Rea, E. Alleviation of salt stress by arbuscular mycorrhizal in zucchini plants grown at low and high phosphorus concentration. Biol. Fertil. Soils 2008, 44, 501-509. [CrossRef]

16. AI-Karaki, G.N. Barley response to salt stress at varied levels of phosphorus. J. Plant Nutr. 1997, 20, 1635-1643. [CrossRef]

17. Abid, M.; Ahmad, F.; Ahmad, N.; Ahmad, I. Effect of phosphorus on growth, yield and mineral composition of wheat in different textured saline-sodic soils. Asian J. Plant Sci. 2002, 1, 472-475. [CrossRef]

18. Shibli, R.A.; Sawwan, J.; Swaidat, I.; Tahat, M. Increased phosphorus mitigates the adverse effects of salinity in tissue culture. Commun. Soil Sci. Plant Anal. 2001, 32, 429-440. [CrossRef]

19. Mohammad, M.; Shibli, R.; Ajlouni, M.; Nimri, L. Tomato root and shoot responses to salt stress under different levels of phosphorus nutrition. J. Plant Nutr. 1998, 21, 1667-1680. [CrossRef]

20. Mohammad, M.J.A.-M. Wheat Growth and P Uptake Responses to Mycorrhizal Inoculation and Deep P Placement. Ph.D. Thesis, Washington State University, Pullman, WA, USA, 1993.

21. Phang, T.-H.; Shao, G.; Liao, H.; Yan, X.; Lam, H.-M. High external phosphate (Pi) increases sodium ion uptake and reduces salt tolerance of 'Pi-tolerant'soybean. Physiol. Plant. 2009, 135, 412-425. [CrossRef]

22. Naheed, G.; Shahbaz, M.; Akram, N.A. Interactive effect of rooting medium application of phosphorus and NaCl on plant biomass and mineral nutrients of rice (Oryza sativa L.). Pak. J. Bot. 2008, 40, 1601-1608.

23. Rogers, M.E.; Grieve, C.M.; Shannon, M.C. Plant growth and ion relations in lucerne (Medicago sativa L.) in response to the combined effects of $\mathrm{NaCl}$ and P. Plant Soil 2003, 253, 187-194. [CrossRef]

24. Champagnol, F. Relationships between phosphate nutrition of plants and salt toxicity. Phosphorus Agri. 1979, $76,35-43$.

25. Manchanda, H.R.; Sharma, S.K.; Bhandari, D.K. Response of barley and wheat to phosphorus in the presence of chloride and sulphate salinity. Plant Soil 1982, 66, 233-241. [CrossRef]

26. Tognetti, R.; Palladino, M.; Minnocci, A.; Delfine, S.; Alvino, A. The response of sugar beet to drip and low-pressure sprinkler irrigation in southern Italy. Agric. Water Manag. 2003, 60, 135-155. [CrossRef]

27. Marschner, H. Mineral Nutrition of Higher Plants; Academic Press: London, UK, 1995; p. 889.

28. Katerji, N.; Van Hoorn, J.W.; Hamdy, A.; Mastrorilli, M.; Karzel, E.M. Osmotic adjustment of sugar beets in response to soil salinity and its influence on stomatal conductance, growth and yield. Agric. Water Manag. 1997, 34, 57-69. [CrossRef]

29. FAO Google Search I Food and Agriculture Organization of the United Nations. Sugar Beet White Sugar. Available online: http:/ / www.fao.org/home/search/en/?q=sugar\%20beet (accessed on 20 January 2021).

30. Debbarh, A.; Badraoui, M. Irrigation et Environnement au Maroc: Situation Actuelle et Perpectives. Atelier du PCSI (Programme Commun Systèmes Irrigués) sur une Maîtrise des Impacts Environnementaux de l'Irrigation: Montpellier, France, 2001; 14p, ffcirad-00179840. Available online: https:/ / www.researchgate.net/signup.SignUp.html (accessed on 22 June 2021).

31. Jackson, M.L. Soil Chemical Analysis: Advanced Course. UW-Madison Libraries Parallel Press: Madison, WI, USA, 2005.

32. Dahnke, W.C.; Whitney, D.A. Recommended Chemical Soil Test Procedures; North Central Regional Research Publication: Columbia, MO, USA, 1988; Volume 221.

33. Reinefeld, E.; Emmerich, A.; Baumgarten, G.; Winner, C.; Beiss, U. Zur Voraussage Des Melassezuckers Aus Rubenanalysen. Zucker 1974, 27, 2-15.

34. Moreno, F.; Cabrera, F.; Fernández-Boy, E.; Girón, I.F.; Fernández, J.E.; Bellido, B. Irrigation with saline water in the reclaimed marsh soils of south-west Spain: Impact on soil properties and cotton and sugar beet crops. Agric. Water Manag. 2001, 48, 133-150. [CrossRef] 
35. Gupta, D.K. Prospect of Sugar Beet Based Commercially Viable Industries in the Backward Coastal Saline Tract of the Country. In Transferable Technology for Rural Development; Das Gupta, D.K., Ed.; Associated Publishing Company: New Delhi, India, 1985; pp. 124-133.

36. Ayars, J.E.; Schoneman, R.A. Irrigating field crops in the presence of saline groundwater. Irrig. Drain. 2006, 55, 265-279. [CrossRef]

37. Lycoskoufis, I.H.; Savvas, D.; Mavrogianopoulos, G. Growth, gas exchange, and nutrient status in pepper (Capsicum annuum L.) grown in recirculating nutrient solution as affected by salinity imposed to half of the root system. Sci. Hortic. 2005, 106, 147-161. [CrossRef]

38. Jamil, M.; Rehman, S.; Rha, E.S. Salinity effect on plant growth, PSII photochemistry and chlorophyll content in sugar beet (Beta vulgaris L.) and cabbage (Brassica oleracea capitata L.). Pak. J. Bot. 2007, 39, 753-760.

39. Mostafavi, K. Effect of salt stress on germination and early seedling growth stage of sugar beet cultivars. Am. Eurasian J. Sustain. Agric. 2012, 6, 120-125.

40. Ghoulam, C.; Foursy, A.; Fares, K. Effects of salt stress on growth, inorganic ions and proline accumulation in relation to osmotic adjustment in five sugar beet cultivars. Environ. Exp. Bot. 2002, 47, 39-50. [CrossRef]

41. Zaki, N.M.; Hassanein, M.S.; Amal, G.A.; Ebtsam, A.; Tawfik, M.M. Foliar application of potassium to mitigate the adverse impact of salinity on some sugar beet varieties. 2: Effect on yield and quality. Middle East J. Agric. Res. 2014, 3, 448-460.

42. Khafagi, O.M.A.; El-Lawandy, W.I. Salt tolerance of table beet (Beta vulgaris, L.). I. Metabollic products and ion accumulation. Ann. Agric. Sci. Moshtohor Prod. 1996, 34, 1663-1947.

43. Heuer, B.; Plaut, Z. Photosynthesis and osmotic adjustment of two sugarbeet cultivars grown under saline conditions. J. Exp. Bot. 1989, 40, 437-440. [CrossRef]

44. Eid, S.; Ibrahim, M. Irrigation water salinity and irrigation inter-vals effects on growth, yield and quality of the sugar beet, in saline soil, at middle north Nile delta. J. Soil Sci. Agric. Eng. 2010, 1, 789-800. [CrossRef]

45. Çimrin, K.M.; Türkmen, Ö.; Turan, M.; Tuncer, B. Phosphorus and humic acid application alleviate salinity stress of pepper seedling. Afr. J. Biotechnol. 2010, 936, 5845-5851.

46. Mundree, S.G.; Baker, B.; Mowla, S.; Peters, S.; Marais, S.; Vander Willigen, C.; Govender, K.; Maredza, A.; Muyanga, S.; Farrant, J.M. Physiological and molecular insights into drought tolerance. Afr. J. Biotechnol. 2002, 1, 28-38.

47. Hajiboland, R.; Joudmand, A.; Fotouhi, K. Mild salinity improves sugar beet (Beta vulgaris L.) quality. Acta Agric. Scand. Sect. B Plant Soil Sci. 2009, 59, 295-305. [CrossRef]

48. Feizi, M.; Fallahzade, J.; Noorshargh, P. Sugar beet yield response to different levels of saline irrigation water and leaching in an arid region. J. Plant Nutr. 2018, 41, 654-663. [CrossRef]

49. Hussain, Z.; Khattak, R.A.; Irshad, M.; Mahmood, Q. Sugar beet (Beta vulgaris L.) response to diammonium phosphate and potassium sulphate under saline-sodic conditions. Soil Use Manag. 2014, 30, 320-327. [CrossRef]

50. Khan, M.A.A.; Singhania, R.A.; Mishra, N.P. Effect of nitrogen and phosphorus on yield and quality of sugar beet in saline-sodic soils. Acta Agron. Hung. 1990, 39, 381-387.

51. El-Tilib, M.A.; Elnasikh, M.H.; Elamin, E.A. Phosphorus and potassium fertilization effects on growth attributes and yield of two sugarcane varieties grown on three soil series. J. Plant Nutr. 2004, 27, 663-699. [CrossRef]

52. Bargaz, A.; Nassar, R.M.A.; Rady, M.M.; Gaballah, M.S.; Thompson, S.M.; Brestic, M.; Schmidhalter, U.; Abdelhamid, M.T. Improved salinity tolerance by phosphorus fertilizer in two Phaseolus vulgaris recombinant inbred lines contrasting in their P-efficiency. J. Agron. Crop Sci. 2016, 202, 497-507. [CrossRef]

53. Abdel-Mawly, S.E.; Zanouny, I. Response of sugar beet (Beta vulgaris, L.) to potassium application and irrigation with saline water. Ass. Univ. Bull. Environ. Res. 2004, 7, 14.

54. Munns, R. Comparative physiology of salt and water stress. Plant Cell Environ. 2002, 25, 239-250. [CrossRef]

55. Bajji, M.; Lutts, S.; Kinet, J.-M. Water deficit effects on solute contribution to osmotic adjustment as a function of leaf ageing in three durum wheat (Triticum durum Desf.) cultivars performing differently in arid conditions. Plant Sci. 2001, 160, 669-681. [CrossRef]

56. Hosford, D.J.; Lenton, J.R.; Milford, G.F.J.; Pocock, T.O.; Elliott, M.C. Phytohormone changes during storage root growth in Beta species. Plant Growth Regul. 1984, 2, 371-380. [CrossRef]

57. El-Maghraby, S.S.; Sam, M.M.S.; Tawfik, Y.H. Effect of soil and foliar application of nitrogen and potassium on sugar beet. Egypt. J. Agric. Res. Egypt 1998, 7, 665-679.

58. Khalil, S.M.; Mostafa, S.N.; Mostafa, Z.R. Influence of potassium fertilizer and soil salinity on chemical composition of sugar beet root. Minufiya J. Agric. Res. 2001, 26, 583-594.

59. Shahriaripour, R.; Tajabadi Pour, A.; Mozaffari, V. Effects of salinity and soil phosphorus application on growth and chemical composition of pistachio seedlings. Commun. Soil Sci. Plant Anal. 2011, 42, 144-158. [CrossRef]

60. Dadkhah, A.R. Response of root yield and quality of sugar beet (Beta vulgaris) to salt stress. Iran Agric. Res. 2005, $23,31-42$. [CrossRef]

61. Thouraya, R.; Imen, I.; Imen, H.; Riadh, I.; Ahlem, B.; Hager, J. Effet du stress salin sur le comportement physiologique et métabolique de trois variétés de piment (Capsicum annuum 1.). J. Appl. Biosci. 2013, 66, 5060. [CrossRef]

62. Zribi, L.; Gharbi, F.; Rezgui, F.; Rejeb, S.; Nahdi, H.; Rejeb, M. Effets du stress salin sur la croissance et sur les mécanismes de photoprotection chez la tomate. In Proceedings of the Actes des Journées Scientifiques de l'INRGREF, Hammamet, Tunisia, 21-22 November 2007. 